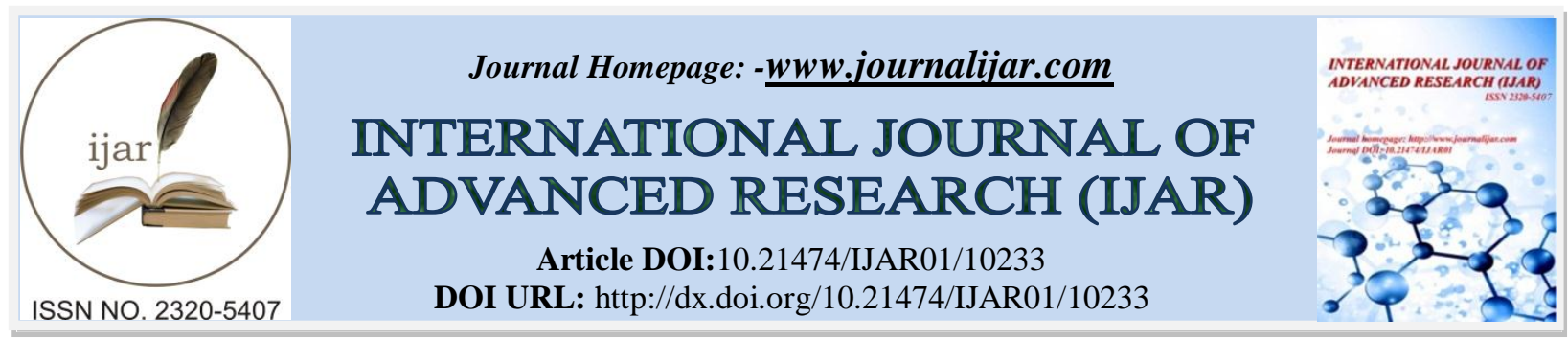

RESEARCH ARTICLE

\title{
IMPACT ON VOTERS OF THE EFFORTS OF THE STATE'S DEPARTMENT OF INFORMATION AND PUBLIC RELATION FOR DISSEMINATING THE ACHIEVEMENTS OF THE STATE GOVERNMENT IN THE BORDER AREAS: (SPECIAL REFERENCE TO KHAJUWALA, DISTRICT BIKANER, RAJASTHAN
}

Himanshu Singh Saini

Research Scholar (JRF), Center For Mass Comm,University of Rajasthan, Jaipur.

\section{Manuscript Info}

Manuscript History

Received: 12 October 2019

Final Accepted: 14 November 2019

Published: December 2019

\section{Abstract}

Copy Right, IJAR, 2019,. Al l rights reserved.

\section{Introduction:-}

Since time immemorial, Public Relation have contributed significantly to the administrative system. Public Relation have traveled a long way in the journey from proclamation in ancient times to the propaganda campaign in modern times. The Department of Information and Public Relation has been active since independence in the state also. The main function of the Department of Information and Public Relation is to act as a bridge between the government and the media, as well as to publicize the schemes of the public interest among the general public, so as to increase the popularity of the government.

Since Rajasthan is a geographically heterogeneous region, there are areas which range from plains to hilly Thar desert, where the access of media, development plans and administrative authorities is not as easy as in the capital region, urban area or other flat parts of the state. It would be interesting and expedient to know in Bikaner district, bordering the Indo-Pak border how much the Department of Information and Public Relation (DIPR) has played in propagating the information about government schemes especially about the farmers' schemes. It becomes quite necessary to raise this information because in the last assembly elections, the Congress party had won with a huge margin in the region, but in the Lok Sabha elections that were held barely six months later, it had to face the defeat. Therefore, was it the failure of the Department of Information and Public Relation in delivering the government schemes in this agricultural land as the Lok Sabha election results were considered as the results of 6 months of functioning of welfare schemes by the state government. It will also be cleared through the research that the farmers get benefits from the schemes run for them whether through media or through some opinion leaders. Since the DIPR has also started partially working through new media, it will also be interesting to know how successful the Public Relation Department is in delivering and communicating the information about government schemes and policies to the general public through new media like news about other incidents happening in the country.

\section{Research area:}

The field study area chosen for this study is Khajuwala, the border assembly constituency of Western District Rajasthan, Bikaner. Khajuwala is a border subdivision, tehsil, panchayat Samiti and assembly constituency. The selection of Khajuwala is appropriate because the highest vote swing was seen here. The Congress won with the largest margins (by 31089 votes) in the assembly elections, while the Lok Sabha elections trailed by 18324 votes from the same assembly constituency. That means congress lost about 49000 voters there. Hence, the study will also 
try to clarify the circumtances to which extent the propagation of Public Relation and information affects the general public and voters or if there is any other factor that affects the voters' mindset.

\section{Research Objectives:}

Research will enable us to know the extent of success in efforts being made by the State Department of Information and Public Relation to convey the information of the schemes to the general public.

Khajuwala has been one of the centres of the Kisan agitation. Irrigation water has been a major issue in the last 2 decades, that too was provided on time this year. Along with that, the state Government announced a loan waiver for the farmers, the credit waiver of cooperative banks, but still the people were not convinced to vote in favour of the ruling party in the state. This research work will also be looking into the reasons behind it.

It will be an attempt to know the lacunas in efforts made by the Public Relation department to propagate and deliver the schemes of public interest in six months that made people not to vote in favor of the ruling party in Lok Sabha election.

Were the schemes of public interest by the state government and state level issues really effective at the time of voting in the Lok Sabha elections or were it fought on completely different issues from the assembly election?

To make the state government scheme and achievements accessible in the remote areas the DIPR uses which medium of mass communication, will be known and the reason for the medium that are not in use will also be known.

Apart from the Public Relation Department, how much the local opinion leaders reach out the public in the remote areas to inform about state government's plans and achievement? Are they more influential than the Department of Information and Public Relation?

The research will try to find out if there is any special policy for communication by the State's Information and Public Relation Department in border areas.

\section{Research Hypothesis:}

The State Information and Public Relation Department has failed in providing the information about schemes and achievements of the State Government especially about agriculture in the remote areas of the assembly constituency. The State Government's achievements and schemes could not be reached to the common masses due to lack of innovation in mediums of publicity or less use of new media by the Department of Information and Public Relation of the State.

The hindrances in administrative mechanism made the schemes and public announcements a little accessible to general public that did not give entire benefits of them to the voters.

Local political equations, factionalism also influenced voters.

After the Pulwama attack and Balakot air strike, a kind of nationalist atmosphere was also created that led the voters in favor of centrally ruling party by bypassing the welfare schemes, facilities and benefits of state government.

\section{Research Techniques:}

For the compilation of primary data in the research, 3 Gram Panchayats were selected from Simple Random Sampling of the Gram Panchayats along the Indo-Pak International Border (0-10 km distance) in Khajuwala Assembly constituency. After this, 3 villages with the most dense population of those three gram panchayats will be selected for study. In which interview will be held with 30-30 respondents each.

Along with the respondents, local public representatives, representatives of political parties at the local level, local officials of the agriculture department, local legislators, district information and Public Relation Officers will be interviewed. The secondary source will be various materials received from the Border Area Development Program, Census and Statistics Department, Agriculture Department, State Election Commission and Information and Public Relation Department. Since this area is agriculture and irrigation oriented, the study will include the study on the 
information that people know about the schemes run by government in the field of irrigation and agriculture, and the steps like loan waivers, and the information that the Information and Public Relation Department has contributed in communicating the information to the people.

\section{Sample Selection:}

The entire research area i.e. Khajuwala Assembly which is also the frontier Panchayat Samiti. There are 45 gram panchayats here. Out of which 23 gram panchayats are $20 \mathrm{~km}$ away from the international border and 14 gram panchayat headquarters are adjacent to the Indo-Pak border 0-10 km. Of these, on selection by lottery method, villages $20 \mathrm{BD}$ (3008), $33 \mathrm{KJD}$ (1038) and $39 \mathrm{KJD}$ (1028) were selected. Various questions were asked from randomly found respondents from selected villages.

\section{Research Results:-}

After participatory observation in each village, the representatives of the people were talked to as well as residents were also asked questions through the questionnaire and interview schedule. When questions were asked to Sarpanch Savita Rani and youth philanthropist Satpal Meghwal in the Village 20 BD, they told that they get information from the newspapers or by the local administration or from the circular send by the Panchayat Samiti in the Gram Panchayat, if government sends them.

Although the information is available due to being connected in the local WhatsApp group, the DIPR of the state does not provide information about new schemes or the information regarding the benefits of schemes. Also, No outdoor advertising has being done by the department. The trend of social media has benefited, but it is mostly limited to the youth, however, poor mobile network is a problem. Local resident Naseem said that the newspaper reaches only government offices and the homes of one or two eminent people. Mostly they read newspapers on the chaupal. The Android phone is out of their reach due to financial constraints. The reason for the Congress falling behind in the Lok Sabha elections was that both the nationalist wave after Pulwama attack and News Channel debates where Congress has a weak candidate.Naseem believes that the local MLA's team was also inactive after his daughter Sarita Chauhan was denied the ticket for MP. At the same time, Anmol Sharma described it as the result of the Modi wave. Out of the major 6 government schemes run by the state government, only 16 of 26 respondents knew about loan waiver. No one knew about the livestock insurance scheme, not even the local sarpanch. In the Panchayati Raj election, 18 out of 26 respondents knew about changing the qualification. Only the local sarpanch and another respondent knew about giving one lakh agricultural connections and not raising electricity rates on agricultural connections for five years. 11 respondents were aware of raising the pension amount by Rs 250 , while 3 respondents were aware of starting pension for small and marginal farmers. Out of 26 respondents, 5 from local leaders, 2 from government employees, 16 from friends and relatives and 3 from media reported meeting on the question of where government schemes are run. Regarding the impact of the Lok Sabha elections on welfare schemes by the state government, the local representatives said that this was not made an issue even by the local Congress workers.

During the survey and interview conducted at 33 KJD booth of Gram Panchayat 2KLD (0RD), former sarpanch Pemaram Godara said that irrigation water was found, but after the Pulwama attack, Modi wave suppressed the functioning of the state government. The state government may have done the work, but no information other than loan waiver has reached here. The benefit of debt waiver was also not received. At the same time Krishnakumar Kasani also said that the administrator of the cooperative society did not give the benefits of loan waiver and took bribe. Here 27 out of 30 respondents got the benefit of debt waiver. At the same time, no one was aware of the livestock insurance scheme. Small and marginal farmers did not even know about the pension, although there were 17 informed people who knew about increased amount of pension to 250 rupees. Upsarpanch Mukharam Suthar told that only then we will be able to take advantage of the schemes. Social media apps like WhatsApp do not work here due to weak network, and no TV program airs the details about such plans. Newspaper is also not regularly available.Total 3 out of 30 respondents knew about giving one lakh agricultural connections and not increasing the electricity rates on agricultural connections for five years, this information was also available only in the subdivision office Khajuwala. From where do you know about government schemes? In response to this, 23 out of 30 told, from friends and relatives, 3 from local leaders, 3 from the newspaper or media when they went to Khajuwala, while one person told that he gets it from the Gram Sevak i.e. government employee.

After this, the researcher reached 39 KJD Gram Panchayat Booth of Anandgarh. 39 KJD is just $3 \mathrm{~km}$ from the border. Various development works have also been carried out by the Border Security Force (BSF) here. Deepdas 
Swamy of here said that the Modi wave was the only reason for Congress's defeat. Surjaram Nayak said that there is no attention towards the solution of the problems here, no matter from which party the leader is. Due to the remoteness, they are not able to reach the media even. Indraj Saharan said that the benefits of debt waiver and increased pension have been received from government schemes. The trend in favor of the Congress was also visible due to the availability of complete irrigation water, but the BJP won because of the Modi wave. Of the 24 respondents here, 20 were aware of debt waiver, while no one was aware of livestock insurance scheme. 2 respondents were also aware about pension to small and marginal farmers, 12 respondents were aware of raising pension amount by Rs 250.6 respondents were aware of giving one lakh agricultural connections and not raising electricity rates on agricultural connections for five years. Where do you know about government schemes? Out of 24,14 of the 24 respondents reported meeting with friends and relatives, 6 with local leaders, 4 meeting with newspapers, TV, whatsapp.

Apart from this, where the local MLA told the reason behind defeat was that the ticket was given to a wrong candidate, the District Information and Public Relation Officer said that advertisements are issued about the schemes on newspaper and TV. The contract is given to the concerned firm for external advertising, but the information of the schemes can be conveyed to the remote areas either by extension of media or by any other means. Because having responsibility of such a large area for a Public Relation Officer is a problem. No effort is made to convey information to the media, but where there is no media, we have to think about how to make the information accessible.

According to Table 1, 78.75 percent of the respondents were aware of debt waiver, while not a single one was aware of livestock insurance. 50\% of the respondents were aware of the increase in pension amount, as the increased amount was received in the account of pensioners in the village. On the other hand, information about starting pension for small and marginal farmers was 6.75 percent available, 13 percent of the respondents were given information about giving 1 lakh agricultural connections and not increasing the electricity rate.

According to Table 2, 66.25 percent of the respondents get information about government schemes from friends or relatives, while 17.50 percent from local leaders and 12.50 percent from media, while 3.75 percent from government employees or other sources.

\section{Conclusion:-}

Research showed that the schemes of the State Government, the schemes of the Information and Public Relation Department, do not reach the local level in the border area through the media. Out if 6 flagship schemes that were focused here, only 2 were known by the people and 50\% of those people knew about it because their bank accounts were linked with them. The 'Sujas' magazine published by the Information and Public Relation Department at the local level also does not reach, whereas 35 thousand copies of this magazine are published. In such a situation, if copies of Sujas are sent to the local gram panchayat, ward panch, local Public representatives, then the information of government schemes will definitely reach the general public. Because local leaders (opinion leaders) have a significant contribution in the transmission of information. Apart from this, the district information and Public Relation Officers have heavy workload, therefore, they have not enough time to spend on informing people about schemes except issuing press notes. Because of vast work area, it is quite difficult to make the information about schemes accessible or monitor it. Therefore, it will be helpful for the the government to appoint a information and Public Relation Officer for rural areas or counterpart position just like a additional Officer in police for rural areas. It is clear from the research result that Modi wave, Pulwama attack overshadowed the schemes run by the state government. Information about these schemes also does not reach the voters adequately. Even if it did reach, the result would probably have been more or less the same due to the nationalist wave. Apart from this, in rural and countryside areas, the State Government will have to insist on giving information about schemes through external advertisement and folk arts.

\section{Questionnaire:}

1. Name

2. Age

3. Caste

4. Residence

5. Education

6. Business 


\section{Do you get newspaper daily? ( Yes/ no):}

If yes, which one Page that you read in newspaper

1. Latest news from last two days?

2. Do you have TV or radio at home? (Yes/no)

3. Radio or TV or both??

What do you listen on radio.

Preferred channels on TV.

Any special programs that is watched regularly.

From where do you get news about government schemes

1. Local leader

2. Government employees

3. Friends

4. Media

Schemes by the present state government, that you know about:

1. Loan waiver yes/no

2. Increased pension yes/no

3. Pension scheme for small farmers yes/no

4. Free insurance for livestock yes/no

5. 1 lac agricultural connection yes/no

6. Changes in criteria for punchayat election yes/no

Did you get benefitted from any scheme, how many.

Why congress trailed behind in 2019 loksabha election after a huge victory earlier?

Main reason for defeat of congress?

Tabulation:

Table 1:-

\begin{tabular}{|l|l|l|l|l|l|}
\hline S. No. & Research Question & & & & Percentage \\
\hline 1 & Respondent knows about Loan wavier & 63 & Total Respondent & 80 & 78.75 \\
\hline 2 & $\begin{array}{l}\text { Respondent knows about Free insurance for } \\
\text { livestock }\end{array}$ & Total Respondent & 80 & 00.00 \\
\hline 3 & $\begin{array}{l}\text { Respondent knows aboutIncreased pension amount } \\
\text { Respondent knows aboutPension scheme for small }\end{array}$ & 05 & Total Respondent & 80 & 50.00 \\
\hline 4 & $\begin{array}{l}\text { Tarmers Respondent } \\
\text { cospondent knows about1 lac agricultural }\end{array}$ & 80 & 6.25 \\
\hline 5 & $\begin{array}{l}\text { Respondents having knowledge about not } \\
\text { increasing electricity rate in agricultural use for 5 } \\
\text { years }\end{array}$ & Total Respondent & 80 & 13.75 \\
\hline
\end{tabular}

Table 2:-

\begin{tabular}{|l|l|l|l|l|}
\hline $\begin{array}{l}\text { S. } \\
\text { No. }\end{array}$ & Means of accessing information about government schemes & & Total Respondent & Percentage \\
\hline 1 & Friends/Family Member & 53 & 80 & 66.25 \\
\hline 2 & Local Opinion Leader & 14 & 80 & 17.50 \\
\hline 3 & Media & 10 & 80 & 12.50 \\
\hline 4 & Govt Servant or Other Source & 03 & 80 & 3.75 \\
\hline & Total & 80 & 80 & 100 \\
\hline
\end{tabular}


Description of voting status in selected villages:

Table 3:- Dist- Bikaner Legislative Constitution Area- Khajuwala; Village: 20 BD Gram Panchayat: 20 B D, Population - 3008, Total Voters- 1107 Male Voters- 584, Female Voters - 523.

\begin{tabular}{|l|l|l|l|l|l|l|}
\hline $\begin{array}{l}\text { Assemble } \\
\text { Election } \\
2018\end{array}$ & $\begin{array}{l}\text { Vote } \\
\text { Received }\end{array}$ & $\begin{array}{l}\text { Voting } \\
\text { Percentage }\end{array}$ & $\begin{array}{l}\text { Parliamentary } \\
\text { Election2019 }\end{array}$ & $\begin{array}{l}\text { Vote } \\
\text { Received }\end{array}$ & $\begin{array}{l}\text { Voting } \\
\text { Percentage }\end{array}$ & $\begin{array}{l}\text { Difference in } \\
\text { voting } \\
\text { percentage }\end{array}$ \\
\hline Congress & 393 & 46.34 & Congress & 212 & 46.34 & $19.34-\%$ \\
\hline BJP & 403 & 47.52 & BJP & 547 & 47.52 & $21.65+\%$ \\
\hline Other & 46 & 5.42 & Other & 19 & 5.42 & $-03.00 \%$ \\
\hline Nota & 06 & 0.70 & Nota & 07 & 0.89 & $+0.19 \%$ \\
\hline Total Vote & 848 & & Total vote & 785 & & \\
\hline
\end{tabular}

Table 4:- Dist- BikanerLegislative Constitution Area- Khajuwala; Village: 39 KJD; Gram Panchayat: Aanandgarh,Polulation - 1028 (2011 Census), TotalVoters- 1232(Dec 2018)Male Voters- 352, Female Voters- 297.

\begin{tabular}{|l|l|l|l|l|l|l|}
\hline $\begin{array}{l}\text { Assemble } \\
\text { Election } \\
2018\end{array}$ & $\begin{array}{l}\text { Vote } \\
\text { Received }\end{array}$ & $\begin{array}{l}\text { Voting } \\
\text { Percentage }\end{array}$ & $\begin{array}{l}\text { Parliamentary } \\
\text { Election2019 }\end{array}$ & $\begin{array}{l}\text { Vote } \\
\text { Received }\end{array}$ & $\begin{array}{l}\text { Voting } \\
\text { Percentage }\end{array}$ & $\begin{array}{l}\text { Difference in } \\
\text { voting } \\
\text { percentage }\end{array}$ \\
\hline Congress & 386 & $43.96 \%$ & Congress & 227 & $28.55 \%$ & $15.41-\%$ \\
\hline BJP & 339 & $38.61 \%$ & BJP & 533 & $67.04 \%$ & $28.43+\%$ \\
\hline Other & 145 & $16.51 \%$ & Other & 31 & $03.89 \%$ & $-12.60 \%$ \\
\hline Nota & 08 & $0.91 \%$ & Nota & 04 & $0.50 \%$ & $-0.41 \%$ \\
\hline Total Vote & 878 & & Total vote & 795 & & \\
\hline
\end{tabular}

Table 5:-Dist -BikanerLegislative Constitution Area -Khajuwala; Village: 33 KJD; Gram Panchayat: 2 KLD 0) RD,(Population, 1038 - Total Voters 533 -Male Voters ,290 -Female Voters.243 -

\begin{tabular}{|l|l|l|l|l|l|l|}
\hline $\begin{array}{l}\text { Assemble } \\
\text { Election } \\
\mathbf{2 0 1 8}\end{array}$ & $\begin{array}{l}\text { Vote } \\
\text { Received }\end{array}$ & $\begin{array}{l}\text { Voting } \\
\text { Percentage }\end{array}$ & $\begin{array}{l}\text { Parliamentary } \\
\text { Election2019 }\end{array}$ & $\begin{array}{l}\text { Vote } \\
\text { Received }\end{array}$ & $\begin{array}{l}\text { Voting } \\
\text { Percentage }\end{array}$ & $\begin{array}{l}\text { Difference in } \\
\text { voting } \\
\text { percentage }\end{array}$ \\
\hline Congress & $\mathbf{1 7 0}$ & $\mathbf{4 4 . 7 3} \%$ & Congress & $\mathbf{1 3 9}$ & $\mathbf{4 2 . 9 0} \%$ & $\mathbf{0 1 . 8 3 -} \%$ \\
\hline BJP & $\mathbf{1 7 9}$ & $\mathbf{4 7 . 1 0} \%$ & BJP & $\mathbf{1 7 5}$ & $\mathbf{5 4 . 0 1} \%$ & $\mathbf{0 6 . 9 1 +} \%$ \\
\hline Other & $\mathbf{3 0}$ & $\mathbf{7 . 8 9} \%$ & Other & $\mathbf{1 0}$ & $\mathbf{3 . 0 8} \%$ & $\mathbf{- 4 . 8 1} \%$ \\
\hline Nota & $\mathbf{0 1}$ & $0.26 \%$ & Nota & $\mathbf{0 0}$ & $\mathbf{0 . 0 0} \%$ & $-0.26 \%$ \\
\hline Total Vote & $\mathbf{3 8 0}$ & \multicolumn{7}{|l|}{ Total vote } & $\mathbf{3 2 4}$ & & \\
\hline
\end{tabular}

\section{References:-}

1. Jethwani Jaishree, Corporate Communication Principles And Practices, Oxford University Press, New Delh, 2013i ISBN-13: 978-0-19-806365-0

2. Vajpeyi, Upendra, Media Ki Swatantrata Aur Jawabdehi, Center For Mass Communication, University Of Rajasthan, Jaipur, Aug 2005

3. Bhanawat, Dr. Sanjeev, Bharat Me Sanchar Madhyam, Rajasthan Hindi Granth Academy, Jaipur, 2010 ISBN978-81-7137-766-4

4. Bhanawat, Dr. Sanjeev, Vikas Evam Vigyan Sanchar, Rajasthan Hindi Granth Academy, Jaipur, 2010 ISBN978-81-7137-771-8

5. Bhanawat, Dr. Sanjeev, Jansampar Evam Vigyapan, Rajasthan Hindi Granth Academy, Jaipur, 2010 ISBN978-81-7137-769-5

6. Jain, C.M Kaingan, Thomas, Bhanawat, Dr. Sanjeev, Media And Rural Development, University Book House, Jaiur, 2004,

7. Mishra, Vinod Chandra, Geography Of Rajasthan, National Book Trust, New Delhi, 2004. 